\title{
ОСОБЛИВОСТІ ОЦІНЮВАННЯ БОЛЮ У ДІТЕЙ 3 ОСОБЛИВИМИ ПОТРЕБАМИ
}

\author{
С. В. Іванова ${ }^{1}$, Н. Б. Галіяш ${ }^{2}$ \\ 1Запорізький обласний спеціалізований будинок дитини «Сонечко» \\ ${ }^{2}$ ДвНЗ «Тернопільський державний медичний університет \\ імені І. Я. Горбачевського МОЗ Украӥни"
}

\begin{abstract}
У статті порушено проблему необхідності належного оцінювання болю у дітей з особливими потребами задля надання їм ефективної реабілітаційної допомоги. Враховуючи фізіологію персистуючого болю та його негативний вплив на дитячий організм, показано необхідність впровадження релевантних методів оцінювання болю, а саме шкал DAN, CRIES, TVP та FLACC у практику спеціалізованих закладів, які опікуються особами з особливими потребами, зокрема будинків-інтернатів для дітей 3 вадами розумового або фізичного розвитку.
\end{abstract}

\section{PECULIARITIES OF PAIN ASSESSMENT IN CHILDREN WITH SPECIAL NEEDS}

\author{
S. V. Ivanova ${ }^{1}$, N. B. Haliyash ${ }^{2}$ \\ 'Zaporizhzhia Regional Specialized Children's Home "Sonechko" \\ ${ }^{2}$ I. Horbachevsky Ternopil State Medical University
}

In the article authors have raised the problem of the necessity of proper pain assessment in children with special needs in order to provide them with effective rehabilitation assistance. Taking into account the physiology of persistent pain and its negative impact on the child's body, the need to introduce relevant pain assessment methods, namely, DAN, CRIES, TVP and FLACC scales, into the practice of special institutions for persons with special needs, including boarding schools for children with delayed mental or physical development has been shown.

Вступ. У міжнародних правових документах, державних законодавчо-нормативних актах соціального спрямування багатьох країн існує загальновживаний термін - «Children with Special Needs», який застосовують до дітей-інвалідів, дітей із незначними порушеннями здоров'я, соціальними проблемами та навіть обдарованих дітей [1]. В Україні термін «діти з особливими потребами» поширюється на дітей, у яких виявляють порушення психофізичного розвитку, також $є$ такі визначення, як «діти-інваліди та діти з вадами розумового або фізичного розвитку», «діти, які потребують корекції фізичного та (або) розумового розвитку», «діти з обмеженими можливостями здоров'я» тощо. Як бачимо, існують відмінності у трактуванні цього терміна в Україні й за кордоном.

Діти з особливими проблемами потребують сучасного формату реабілітаційної допомоги, ефективного і науково доведеного, із залученням їхній родин.

Медична реабілітація - це комплекс заходів, спрямованих на повне чи часткове відновлення по-

(c) С. В. Іванова, Н. Б. Галіяш, 2018 рушених та (або) компенсацію втрачених функцій ураженого органа чи системи організму. Серед інших завдань реабілітаційної допомоги - попередження чи зниження проявів можливої інвалідності, покращення якості життя, соціальна інтеграція особи в суспільство. Відповідно до визначення ВООЗ, реабілітація повинна забезпечити особам із порушеними в результаті хвороби, травми чи уроджених дефектів, функціями організму максимальне пристосування до нових умов життя [2]. Відділення реабілітаційного напрямку часто формують у складі спеціалізованих закладів, які опікуються особами з особливими потребами, зокрема будинків-інтернатів для дітей з вадами розумового або фізичного розвитку тощо.

Оскільки діти з уродженими чи набутими вадами психомоторного розвитку часто страждають від больового синдрому різного ґенезу та інтенсивності, серед завдань реабілітаційного догляду є своєчасна оцінка болю з метою його виявлення та призначення своєчасних ефективних втручань для його контролю.

Таким чином, метою роботи є дослідження можливих механізмів болю у дітей з особливими потребами 
та з'ясування особливостей його оцінювання у цієї категорії пацієнтів.

Основна частина. Біль $є$ однією з психофізіологічних функцій, які рано формуються і $\epsilon$ пов'язаними з найбільш «древніми» структурами мозку. Всі нейрофізіологічні компоненти, необхідні для сприйняття болю новонародженою дитиною, єу плода вже з середини гестаційного періоду. Незавершена мієлінізація не передбачає відсутність функції нервових волокон, а лише трохи сповільнює час передачі імпульсів, що компенсується більш короткими міжнейронними відстанями. Крім того, больовий поріг у новонароджених $є$ значно нижчим, ніж у старших дітей або дорослих. Маленька дитина не може локалізувати біль, тому відповідна реакція має більш дифузний характер, швидко виснажуючи компенсаторні можливості [3, 4].

У зв'язку з тим, що усунення подразника, що спричинює біль, є вкрай важливим для організму, активуються рефлекторні реакції, які призводять до пригнічення більшості інших рефлексів, які можуть виникати та мати захисний характер. Іншою особливістю больового синдрому в дітей є гіпералгезія [4].

За походженням розрізняють такі види болю, як ноцигенний, нейрогенний, психогенний.

Ноцигенний біль виникає при подразненні нервових закінчень, які ідентифікуються як больові рецептори, або ноцицептори (посі - ушкодження, втрата), i $\epsilon$ чутливими до патологічних подразників або до подразників, які стають патологічними при тривалій дії. Ноцицептори у великій кількості містяться в різних органах, тканинах, із них починається формування соматичного та вісцерального болю. Соматичний біль виникає у м'язах, зв'язках, суглобах, кістках, вісцеральний - при ушкодженні внутрішніх органів. До ноцигенного належать біль при травмах, запаленні, ішемії, післяопераційний біль, біль у хворих онкологічного профілю.

Нейрогенний біль з'являється внаслідок ушкодження нервової системи без подразнення больових рецепторів, його пов'язують із ушкодженням периферійних і центральних структур нервової системи. Зокрема, такий біль виникає при невралгії, невриті, фантомних чи таламічних болях тощо. Він може проявлятися як «біль, що тягне», «обпалює», «стріляє». Часто нейрогенна форма больового синдрому супроводжується повною або частковою втратою чутливості в частині тіла. Часто больові відчуття з'являються у відповідь навіть на незначні подразники. Наприклад, при невралгії біль може спровокувати легкий вітер.
Психогенний біль може виникати за відсутності або у разі незначного ушкодження тканин, коли вирішальним фактором є психоемоційний стан (депресія, психоз, істерія). Такі болі не пов'язані з ураженням організму чи зі ступенем тяжкості ушкодження, а, частіше, «надумані» людиною, однак вони можуть з'являтися на тлі сильного больового синдрому ноцигенного або нейрогенного характеру [5].

Оскільки біль є суб'єктивним симптомом, це робить його складним для виявлення та вимірювання, особливо у тієї категорії пацієнтів, які не можуть висловити свої відчуття словами. Ось чому важлива роль у розпізнаванні й оцінці больового синдрому в дітей раннього віку, а також у тих, хто внаслідок затримки психомоторного розвитку не здатен до ефективного вербального спілкування, полягає у здатності медичного працівника правильно інтерпретувати клінічні дані. У такому разі доцільно звертати увагу на об'єктивні прояви болю - поведінкові (порушення сну, неспокій і плач тощо) та фізіологічні (підвищення чСС та артеріального тиску, зменшення вентиляції легень, м'язове напруження) реакції $[4,6]$.

3 цією метою розроблено декілька шкал оцінки больового синдрому, в основі яких лежать фізіологічні та поведінкові реакції дітей раннього віку у відповідь на болюче подразнення. Серед оціночних шкал, які враховують вираження больових реакцій, ми зупинимося на таких, як:

- Шкала DAN для оцінки болю у новонароджених.

- Шкала CRIES, що рекомендована до застосування у немовлят (0-6 місяців).

- Шкала TVP для оцінки персистуючого болюу дітей до 3 років.

- Шкала FLACC, яка дозволяє оцінити біль у дітей, які не вміють говорити, або дітей, з порушеннями мовної спроможності (6 місяців - 7 років).

Однією з найпопулярніших шкал оцінки болю у новонароджених $є$ шкала DAN (Douleur Aiguedu Nouveaune). Ï̈̈ використовують для оцінки гострого і хронічного болю у новонароджених за зовнішніми ознаками (табл. 1) [4, 6].

Шкалу CRIES (табл. 2) розроблено для використання у новонароджених із 32 тижнів гестаційного віку до 6 місяців. Кожен з п'яти показників цієї шкали (плач, потреба в кисні при сатурації нижче 95 \%, підвищення артеріального тиску і чСС, вираз обличчя і сон) оцінюють 0-2 балів [5, 6].

Шкалу TVP (Touch Visual Pain) було створено для ВІЛ-інфікованих дітей з мультиорганною патологією 
Таблиця 1. Шкала DAN для оцінки болю у новонароджених

\begin{tabular}{|c|c|c|}
\hline Показник & Описання & Бали \\
\hline \multirow[t]{5}{*}{ Вираз обличчя } & Спокійний & 0 \\
\hline & Пхикає, очі то відкриває, то закриває, без гримаси & 1 \\
\hline & Страждальницький вираз непостійний, є періоди спокою & 2 \\
\hline & Страждання на обличчі виражені сильно & 3 \\
\hline & Дуже сильні прояви страждання & 4 \\
\hline \multirow[t]{4}{*}{ Рухи кінцівок } & Спокійні, м'які рухи & 0 \\
\hline & Інтенсивність рухів невелика, $\epsilon$ періоди спокою & 1 \\
\hline & Інтенсивність рухів помірна & 2 \\
\hline & Інтенсивність дуже висока, рухи безперервні & 3 \\
\hline \multirow{4}{*}{$\begin{array}{c}\text { Голос } \\
\text { (дитина не інтубована) }\end{array}$} & Немає жалібних нот & 0 \\
\hline & Короткочасне жалібне скигління & 1 \\
\hline & Плач із перервами & 2 \\
\hline & Тривалий плач із виразом невтішності & 3 \\
\hline \multirow{3}{*}{$\begin{array}{c}\text { Голос } \\
\text { (дитина інтубована) }\end{array}$} & Немає жалібних нот & 0 \\
\hline & Виглядає стривоженим або неспокійним & 1 \\
\hline & Схлипування з перервами & 2 \\
\hline \multicolumn{2}{|r|}{ Всього } & - \\
\hline
\end{tabular}

Примітка. Мінімальний сумарний бал - 0; максимальний - 10. Чим більше отримане число - тим більший дискомфорт відчуває дитина.

Таблиця 2. Шкала CRIES

\begin{tabular}{|c|c|c|c|}
\hline \multirow{2}{*}{ Категорія } & \multicolumn{3}{|c|}{ Бал } \\
\hline & 0 & 1 & 2 \\
\hline $\begin{array}{l}\text { Плач (при болю характерний високотональ- } \\
\text { ний плач) }\end{array}$ & $\begin{array}{l}\text { відсутній або } \\
\text { невисокої } \\
\text { тональності } \\
\end{array}$ & $\begin{array}{l}\text { високої тональ- } \\
\text { ності, але дитину } \\
\text { можна заспокоїти } \\
\end{array}$ & $\begin{array}{l}\text { високої тональності, } \\
\text { дитину неможливо } \\
\text { заспокоїти }\end{array}$ \\
\hline $\begin{array}{l}\text { Чи є необхідною подача О } 2 \text { для підтримки } \\
\text { сатурації крові на рівні } 95 \% \text { і більше (відчут- } \\
\text { тя болю знижує показники оксигенації у дітей) }\end{array}$ & $\begin{array}{l}\text { кисень не } \\
\text { потрібний }\end{array}$ & $\begin{array}{l}\text { потрібно <30 \% кис- } \\
\text { ню в газовій суміші } \\
\text { для оксигенації }\end{array}$ & $\begin{array}{l}\text { потрібно >30 \% кисню } \\
\text { в газовій суміші для } \\
\text { оксигенації }\end{array}$ \\
\hline $\begin{array}{l}\text { Збільшення життєво важливих показників } \\
\text { (АТ і ЧСС) }\end{array}$ & $\begin{array}{l}\text { АТ і ЧСС не } \\
\text { змінилися або } \\
\text { зменшилися } \\
\end{array}$ & $\begin{array}{l}\text { АТ і ЧСС збільши- } \\
\text { лися в межах } 20 \%\end{array}$ & $\begin{array}{l}\text { АТ і ЧСС збільшилися } \\
\text { більше ніж на } 20 \%\end{array}$ \\
\hline $\begin{array}{l}\text { Вираз обличчя (часто біль супроводжується } \\
\text { гримасою, яка характеризується опущенням } \\
\text { брів, мруженням, закриттям очей, заглиблен- } \\
\text { ням носо-губної складки, або відкритими } \\
\text { губами та ротом) }\end{array}$ & $\begin{array}{l}\text { гримаса } \\
\text { відсутня }\end{array}$ & $\begin{array}{l}\text { наявна лише } \\
\text { гримаса }\end{array}$ & $\begin{array}{l}\text { наявна гримаса, а } \\
\text { також звуки відмінні } \\
\text { від плачу (крекіт) }\end{array}$ \\
\hline $\begin{array}{l}\text { Безсоння (оцінку здійснюють на основі стану } \\
\text { немовляти впродовж години, що передує за- } \\
\text { пису) }\end{array}$ & постійно спить & часто прокидається & не спить \\
\hline
\end{tabular}

Примітка. 0-3 - немедикаментозні заходи; 4-6 - призначення неопіоїдних анальгетиків; 6-10 - призначення опіоїдних анальгетиків.

(Albertyn, 2010), втім було валідовано і для оцінювання хронічного персистуючого болю при інших захворюваннях [7]. Вона складається з 10 поведінкових індикаторів, які оцінюють як наявні або відсутні (табл. 3) [6].

ще один метод оцінювання болю, який було розроблено для використання у немовлят і дітей до 7 років, - шкала FLACC (face, legs, activity, cry, consolabylity) ґрунтується на врахуванні п'яти поведінкових ознак, а саме: виразу обличчя, руху ніг, рухливості та активності дитини, плачу і можливість до заспокоєння $[6,8]$.
Оцінку болю повинні проводити кожні 4-6 годин із документацією результатів. Для цього необхідно залучати навчений середній медичний персонал.

Висновки. Біль має негативний вплив на організм дитини у будь-якому віці, призводячи до погіршення перебігу фізіологічних процесів та перешкоджаючи одужанню і реконвалесценції, знижуючи якість життя та зумовлюючи надмірне страждання.

Для того, щоб забезпечити ефективну реабілітаційну допомогу дітям з особливими потребами, 
Табличя 3. Шкала TVP

\begin{tabular}{|l|c|}
\hline \multicolumn{1}{|c|}{ Симптом } & $\begin{array}{c}\text { Наявність } \\
\text { симптому - } 1 \text { бал }\end{array}$ \\
\hline Пальці загинаються догори з твердими ступнями, щиколотки щільно стиснуті & \\
\hline Коліна щільно стиснуті або туго перехрещені & \\
\hline Одна нога прикриває ділянку підгузника & \\
\hline $\begin{array}{l}\text { Грудне і/або нерегулярне дихання, і/або дихання ротом, і/або дихання міжреберними } \\
\text { м'язами, і/або роздування крил носа, і/або потріскування }\end{array}$ & \\
\hline Прискорення або зниження чСС & \\
\hline Руки щільно притиснуті до тіла або схрещені біля обличчя, грудей чи живота & \\
\hline Кулаки (неможливо або складно відкрити пальцем) & \\
\hline Шия несиметрично розміщена на плечах, плечі припідняті & \\
\hline Голова розміщена асиметрично & \\
\hline Напружений вираз обличчя (страх або біль), стиснутий рот, неспокій в очах & \\
\hline
\end{tabular}

Примітка. Максимальна оцінка - 10 балів; сума більше 3 означає наявність болю.

$\epsilon$ важливим вчасно виявляти наявність больового синдрому, що, в свою чергу, $\epsilon$ нелегким завданням. Тому впровадження релевантних методів оцінювання болю, а саме шкал DAN, CRIES, TVP та FLACC у практику

\section{СПИСОК ЛІТЕРАТУРИ}

1. Хто такі «діти з особливими потребами»? [Електронний ресурс] : [Веб-сайт]. - Електронні дані. - «Сирітству - HI!» (http://sirotstvy.net ) 2018 ( БО «Фонд Ріната Ахметова». - Режим доступу : http://sirotstvy.net/ua/ tips-professionals/lawyer/khto-taki-dity-z-osoblyvymypotrebamy-/ (дата звернення 12.12.2018). - Назва з екрана.

2. Организационные основы сестринского дела в реабилитации : учеб. пособ. / Н. Г. Петрова [и др.]. - СанктПетербург : СпецЛит, 2016. - 119 с.

3. Шабалов Н. П. Боль и обезболивание в неонатологии / Н. П. Шабалов, С. Л. Иванов. - М., 2004. - 156 с.

4. Постернак Г. И. Оценка боли у новорожденных и детей раннего возраста / Г. И. Постернак, М. Ю. Ткачева, Т. Е. Соболева // Медицина невідкладних станів. - 2013. № 4 (51). - С. 31-36. спеціалізованих закладів, які опікуються особами 3 особливими потребами, зокрема будинків-інтернатів для дітей з вадами розумового або фізичного розвитку, є своєчасним та необхідним.

5. Методы оценки боли у детей разного возраста / Д. В. Дмитриев, А. В. Катилов, Л. И. Лайко, Е. Е. Вжецон // Дитячий лікар. - 2015. - №1 (38). - С. 8-13.

6. Принципи лікування стійкого болю у дітей з соматичними захворюваннями : набір карток. - К. : ТОВ «Видавничий дім «Калита», 2016. - 12 с.

7. Snoek K. G. Pain indicators for persisting pain in hospitalized infants in a South African setting: an explorative study / K. G. Snoek, M. Timmers, R. Albertyn, M. Van Dijk // J. Pain Palliat Care Pharmacother. - 2015. - Vol. 29 (2). P. 125-132.

8. Іванова С. В. Методи оцінювання болю в дитячому віці / С. В. Іванова, Н. Б. Галіяш // Медсестринство. - 2017. № 4. - C. 38-41. 